\title{
A R T
}

$A N D$

\section{A \\ $\begin{array}{llllll}R & \mathrm{~T} & \mathrm{I} & \mathrm{S} & \mathrm{T} & \mathrm{S}\end{array}$}

B Y

R. W. HASKINS, A. M.

"La Nature est le premier des Artistes."

LEMOINE.

\section{BUFFAL,O :}

PRESS OF A. II. CLATP \& Co

1851. 


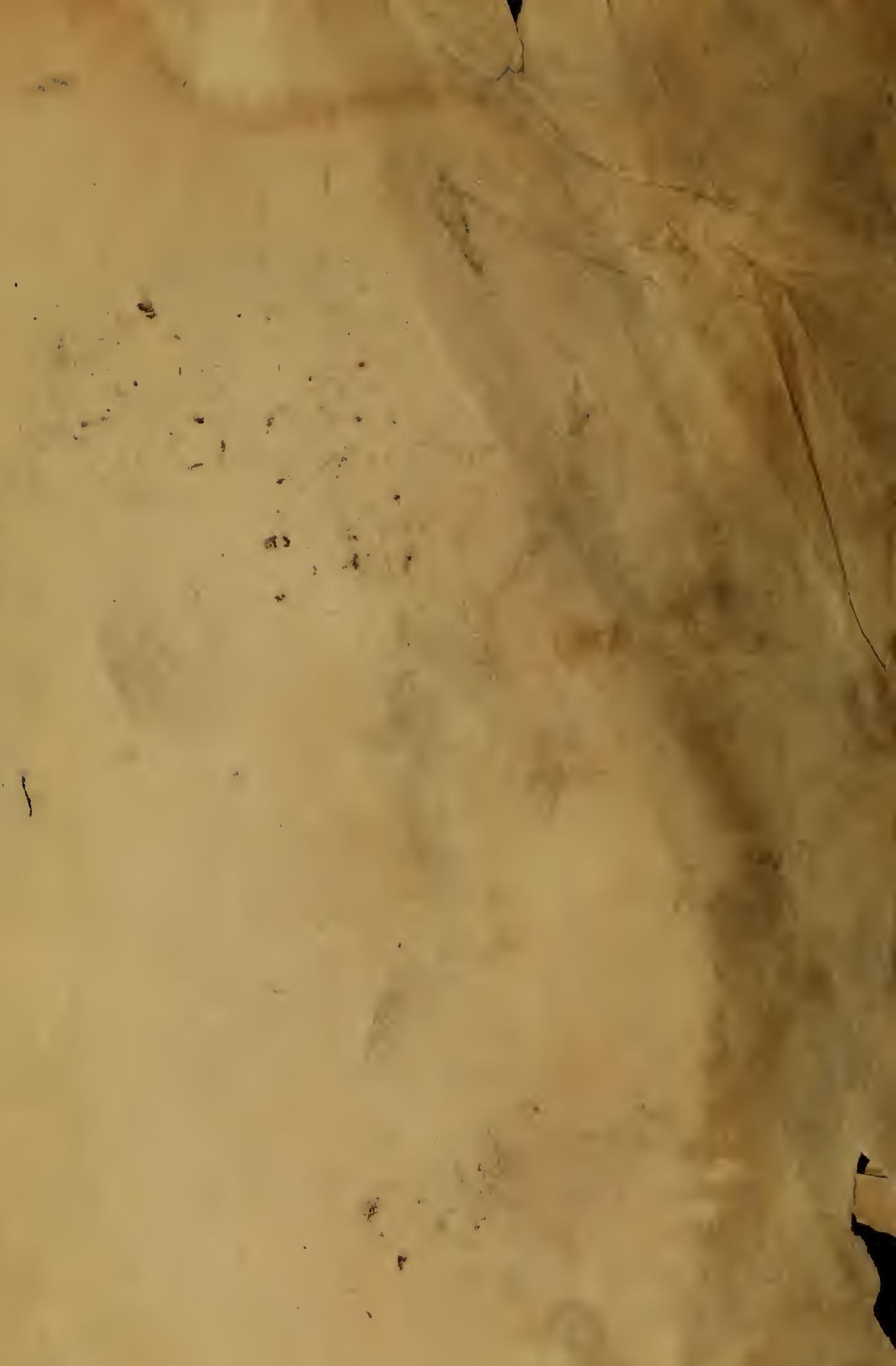

$\because 8$ 


\section{A $\mathrm{R}$ T}

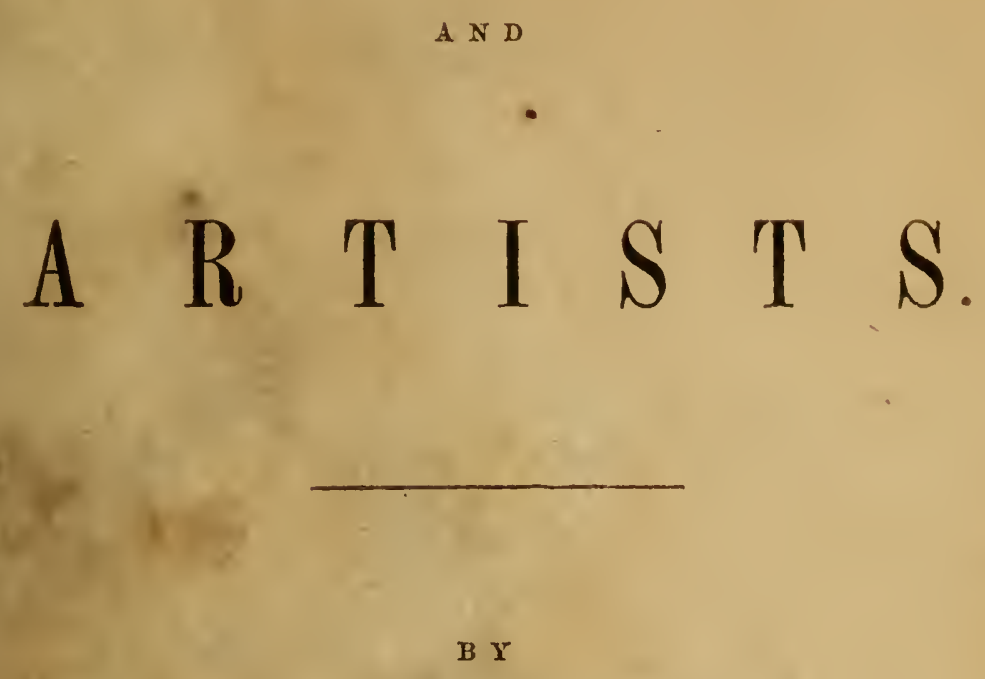

R. W. HASKINS, A. M.

"La Nature est le premier des Artistes."

LEMOINE,

BUFFALO :

PRESS OF A. M. CLAPT \& Co.

1851. 


\section{Entered according to act of Congress, in the year 1850, by}

\section{R. W. HASKINS,}

In the Clerk's Office of the Northern District of New York. 


\section{A R T}

$\Delta \mathrm{N}$

\section{A R T I S T S.}

It is not of these terms, in their widest sense, that we propose here to treat: even Poetry and Statuary we shall barely glance at, as we proceed with our more immediate and direct subject-PAINTrNG.

Human progress, is the abiding alarmist of all tyran. ny, all ignorance, all conservatism-for all these are soulless; and, trom their very nature, incapable of pro. gression. The development of man, here, since the founding of our Reprblic, and under institutions of his own creating has, until recently, been widely deemed but the meteor glare that precedes impending obscuration. Such were the predictions, at least, of Europe; but even Europe now realizes that she has never seen man, until she saw him here, so earnstly and so fiercely pressing onward to the consummation of the higher purposes of his being. In this new career, which our race 
has but just commenced, we have reason to hope for eminence yet unattained, in all that constitutes the true glory of humanity. We have an earnest of all this, not only in the entire absence of every surrounding or contingent restraint upon our energies, but also in the new methods which such absence is sure perpetually to suggest to us for the attainment of the highest desirable ends. In those opening scenes that, in our future, await us, the enactment and the records of which we must leave as mementoes of our age, to those who are to come after us,none can doubt that ART is to fill a wide and glorious field. Poetry, painting and sculpture have all ever pertained to the imperfect forms of civilization through which the Caucassian race has, in various ages, passed; but evidently little has been done, either in civilization, or in ART, compared with what we may justly hope for, as the fruits of the future. Despotism, or tyranny, either political or religous, is wholly incompatible with civilization. We employ this word, of course, in its just and appropriate sense, and by no means in its more common and frivolous signification. Hence we do not include under it, or as in any sense belonging to it, those changeful and effeminate trifles which fashion exclusively signifies by the word: on the contrary, we mean by it, what, alone, it ever did rightfully and really mean, namely, the development of the social and the intellectual state--of the exterior and general condition, and of the interior and personal nature, of man. Civilization, then, and ArT, which is an element of it, can only be developed under forms conceived by thought as broad as the principle that moves aspiring 
man, and free as the spirit that beckons him onward, in his career of greatness, and true glory.

The world-at least the modern world-has ever been a great sufferer by a blind veneration of the past. In all things this veneration is constantly thrust in the face of progressive man; as if to sleep contended with the past, were all that remains to us. The position, of course, implies what, indeed, its defenders constantly assert, namely, that ability, such as can no longer be found here, has pertained to man, upon the earth. This stagnating principle has a life-labor to perform, in resisting natural decay; and it wars upon all original thinkers, because these are disturbers of settled opinions, and such disturbance is detrimental to society, as developed and expounded by this incubus feature of our yet imperfect civilization. But we have not so read God, in his works, as to discover that all of either excellence or greatness has pertained to any specific age. Had they so pertained, then to what wise end has our race been perpetuated beyond that culminating point of its history? No: all evidence reveals to us that every age has its mediocre and its mighty men; and that these last are not always employed,or even willingly tolerated. We were long since poetically told that we may call spirits from the vasty deep, and get no answer; but still we may call genius from obscurity, and it will come. Not that every rude and random shout of ignorance or arrogance has been deemed such call, and so answered; but in no age has the desired response been wanting when invoked in that truthful and relying spirit, which alone has a right to ask, in a cause so 
exalted and so holy. If, therefore, there have been periods of gloom and mental darkness, in human annals, it is because this call is never heard, in times of either stolid satisfaction, or profound indifference, however ignoble or necessitous man's condition may be. In common with all else about us, Ars has been a marked sufferer by the blind veneration of which we have spoken; and in that, no less than in all beside, our first step, in progress, must be to get rid of what is wrong, preparatory to a cordial reception of nature and truth.

The notions we entertain of AnT are generally those which have come to us from Europe; and they are therefor sufficiently old to ensure the admirntion of that conservative principle which looks for age before either goodness or truth, in all it suffers itself to approve. Guided by the views thus brought us from afar, we find that present Europe prefers no first claims, in A $\boldsymbol{s}^{\prime}$, in her own behalf, but is satisfied - yes, proud, even-to base all her claims to art glory upon an humble following of what the artists of Europe are pleased to call the "Old Masters." The first inquiry, then, for us, should be, what place, in the field of Arr, did these old masters occupy? and the second, how far are we prepared to surrender our claims to genius and competency by becoming the mere copyists, of these, or of any masters, whether old or new? And first, of these old masters. The term embraces comparatively few names, but it is usually employed to cover some three hundred years, or from the fourteenth to the seventeenth centuries. This division of time is, in some sort, arbitrary, by which it is made to conform its commencement to the so called re- 
vival of letters - a revival, by the way, of a knowledge of mere words, rather than of tangible realities. As, in its earlier history, AnT had been mostly devoted to objects connected with pagan worship, so, after this "revival," its efforts were largely directed to subjects con. nected with the Jews, our Savior, and the host of saints, of all possible grades, and descriptions, that subsequently came so rapidly into imaginary being. "With few exceptions," says a historian, upon this subject, "the papal power has been the great means of furnishing subjects, and assembling competitors, for the great prizes of painting; and, while their authority was predominant in Europe, we find the brilliant era of the arts, and Rome, the theatre on which it was displayed." The old masters, then, were strictly ecclesiastical beneficiaries; and they had to look, for countenance and support, either directly to the authorities of the Romish church,or to civil princes who all admittedly held power under these. From this social position of the old masters, we readily see what ambition inspired them, and what spirit must have guided thir pencils. There was, for them, no such element as a public, either to employ, or to judge; and they did what would generally be done, in such circumstances, namely, they applied themselves to gratify those to whom, alone, they could look, either for approval or for bread. This would needs sink AnT, as a whole, while it would minutely develope it, in some particulars: and such is just what the works of the old masters prove to have been the result. Regardless of the great lessons of Nature, as a whole, these master's, when they attempted landscape, for instance, 
sought only effect, by deception of the senses-and to this all else was sacrificed. With no love for Nature, and no inspiration derived from her promptings, truth was never exhibited, in their labors, when this would, in the least, interfere with the ignoble result they sought. Their patrons, who were absorbed in the cares of church and state, and who cared little for ART, save in so far as its perversions could be turned to account, for either political or theological purposes, gave no encouragement to the developments of truthful genius, such as alone could exalt ART, or confer artistic glory upon an age. The old masters, thus counselled and thus guided, sank whatever of true greatness they may have possessed, in the more immediate selfishness of subordinate and momentary success. To men thus circumstanced, the incentive to true greatness was wanting: they did not go out to seek the Majesiy of Nature, and to imbibe, from her pure inspirations, a love of that glowing truth that is everywhere met with, in her works. No: they lacked faith that such was their mission; and consequently they perished in the wilderness, without so much as having onee attained to a sight of the promised land. The true place, then, of the old masters, is clearly one which the rising spirit of this nation can never wish to occupy. If Europe, in whole or in part, is content to rest her fame on the praise and the copying of these, be it so: the fate of such must ultimately be that of all mere copyists: and even now, upon those roads where the old masters walked freely, with only the aid of a staff, their modern imitators are already hobbling after them upon crutches. 
If $\mathrm{ArT}$, then, is to come to us, let it come in its purity and its strength, unattainted by false doctrines, and disconnected from the idolatry that conservative fanaticism would fasten upon it. Houseless and a wanderer, under the despotisms of Europe, having no affinities with the people, but supplicating its daily bread, at political courts, and ecclesiastical palaces, ArT has never been able, there, and never will be anywhere, under such circumstances, to exhibit those sublime and exalted powers which its great Author has bestowed upon it. In the social organization which we have established for ourselves, no such place as that occupied by AxT, in Europe, is to be found. Neither his majesty, his highness nor his holiness, those foster fathers of European ART, is here, either to cramp or to misdirect genius. Here, therefore, ArT seeks its long accustomed place, in society, in vain: that place progress has annihilated; and pencil ART appears an adventurer in our midst. Let us hasten, then, to extend a nation's hand and a nation's welcome, to this stranger, while we solemnly install her in the dignity of her new and exalted social position. Leaving as she does, to come among us, cloisters and courts, where she has so long been a recluse, ART, under the new order of things by which she here finds herself surrounded, must first go out and mingle with the world, and learn to know that world, as it really is. Not only must man be thus studied, by her, but all else in Nature, also: skies, clouds, rocks, woods, fields, waters and shores-all, in a word, down even to the humble snowdrop and its tiny shadow, must be conned and known: for here it is not courts 
and cloisters that are either to judge of, or support, Anr, but rather an entire people, who, with far more unbiased incentives to just and exalted appreciations of the endless varieties and beauties of Nature, constantly realize the highest reverence for the sacredness of all her truths. Let ART, then, assume her new social position here, with confidence, nothing doubting; for such contact with the people is her only true place. While state policy or fanatical blindness has, each in its turn, both scorned and persecuted genius, and trampled its labors ignominiously under foot, all TRUE PEOPLE have ever carefully spared and protected pictures, and other ART monuments; even where their social position has denied them the power of doing more. The Goths did this, when they freed the Roman people from imperial despotism; and the misdirected zeal of professing christianity subsequently destroyed, through policy, works of ART which the free devotion of unsophisticated genius had thus reverenced and protected. The French, too, amid all the irregularities incident to great revolutionary movements, have constantly respected AnT; and our own citizen soldiers, while overrunning Mexico, in the late war, studiously guarded from injury the multitude of pencil efforts that everywhere abound, in that country.*

But, we shall be told that pencil art has never been seen in the relation here spoken of, and does not now so exist among us. True, it does not, yet; and the

* A British army deliberately burned the National Library of the United States, at the city of Washington, and as deliberately mutilated a marble monument erected there, by the surviving officers of the attack upon Tripoli, to the memory of their comrades, who fell upon that occasion. These scenes were enacted in 1814. 
fragmentary character of its past existence, with us, is conclusive enough that it is never to be anything, either for itself, or for us, until it shall assume the position indicated. Amid all the multitudinous pencilings that, under the name of ArT, have been produced among us, since we became a nation, there is but here and there one-like angel's visits-that will bear either record, or even casual mention. Far the greater number of all these, of course, have been attempts at portraits. No one, in any considerable degree imbued with the elements of ArT, needs to be told that, with multitudes of aspirants, in this line, form, size and color are esteemed the sole elements of a portrait, and that, from inability to see or appreciate anything beyond these, they are, by all such, implicitly and solely relied upon, for success. Now, all these essentials-and they are such-when in perfection, display all that the tailor and the barber have done; and beside these, they furnish us a carnal image of the man, but no more : the soul, the positive impress of the Deity-the "man in his own image"-is still entirely wanting. We know there have been exceptions to this; and without intending to particularize, among these, and we trust without being deemed in any degree invidious, we may mention the lamented Stewart, whose portraits are well known; and whose head-it is no more-of the late Dr. Bowditch, of Boston, an engraving from which appears in that mathematician's translation of the Mecanique Celeste, exhibits this "presence of the immortal" in a marked degree. Of the few historical, and the multitudinous landscape attempts, that, with 
the portraits, go to make up the sum of American Arr, we shall not be expected here to speak, particularly. They are neither so numerous-we mean those which rise to the character that entitles them to any mention, whatever-nor so equivocally executed as to render a just judgment of them either difficult or uncertain. The evils of all this have been everywhere felt, among us, in so much that the existing nothingness of pencil art has been equally deplored by the public at large, and by professional artists. For the laudable end of remedying this, both informal and legalized organizations have been resorted to, in the hope of exalting pencil art among us. These have appealed directly to the public for the requisite pecuniary means for prosecuting their purposes, and that public has most profusely answered the demands that, in the name of Arr, have been made upon it. At the inception of these organizations, great confidence was created in them; but, as they have been tested, by experience, we find we have hoped for more from them than has been realized. Still, until recently, most have been silent, under the disappointment; mainly, perhaps, from doubts as to the real cause, or of ability to suggest the remedy. But to one entertaining the foregoing views of ART, and its relations, neither the cause of this barenness, nor the remedy for it, is obscure. These organizations have all been created upon that erroneous basis of prevailing opinion to which we have already directed the reader's attention. The parties engaged in their organization and their management, have alike participated in the concession that 
the old masters have clearly surpassed all that can ever come after them, and that, consequently, it only remains, for the rest of mankind, to follow these, at such varied distances as individual capacity shall prescribe, even until time shall be no more! While based upon so iniquitous and degrading an error, these organizations, with whatever of laudable effort, must find actual approach to useful truth impossible; and in their future progress they can scarcely fail, ultimately, to fall into unworthy hands which, thus suddenly called to minister at the altar of a divinity unknown to them, will come, finally, to make mere merchandise of the whole matter, and so dishonor all, as the money changers once did, in the Temple of the living God. Meanwhile, just in proportion as ART is thus degraded, artists become the victims of that degration. Taught, upon every hand, as well from Europe as at home, that they must despair of ever excelling the past, they quietly submit to this supposed decree of fate, and without venturing another single aspiration of true greatness, sink calmly into a state of trifling mediocrity, as the highest sphere to which it is possible for them to attain. And it is evidently from this degraded mental position that most of our artist's picture inceptions have sprung; for it is not to be denied that their productions, as a whole, have been preeminently puerile and commonplace. We speak not, now, of mechanical execution, but only of inception. In this their productions have generally been worthless, because wholly senseless, and without either beginning, end or aim. They are neither natural, historical, nor typical 
-but freely sacrifising all these to the unmeaning and effeminate pretty: a conception fully applicable to the figures upon a dress, or a carpet. Such toys-for they are not pictures-lead to nothing, and from their very nature can produce no effects that are either enduring or desirable. An artist impressed with the views we have indicated, and which have thoroughly removed from his mind every hope, and all thought of greatness, resolves to paint a picture, either to sell, or for exhibition. Now, this resolve has been forced upon him, by his false estimate of his own position; and yet, for the very reason that he has resolved to paint, for either of these mere trade purposes, he has already ensured the failure of his effort. Let us see where this resolution has placed him. Observe, our artist's resolution to paint, for the purpose indicated, precedes all inception of what is to be produced. The next step therefore, is, to select his subject; but his motive being only a groveling one, how can his subject, thus chosen, be anything better? Well: true to his instincts, he decides to paint a beauty; and does so. But, when seen, however successfully executed, neither sex will admit that there is only a single beauty, in the world; and therefore he finds that he has, at the best, only one beauty, of the whole number of beauties, and that no particular one; and so, consequently, his piece neither has excited nor ever can excite, any other than the most general. and feeble interest. Failing to discover the cause of his discomforture, he vents some teeling, perhaps, upon what he deems the world's want of appreciation, and then tries again. With object still the same, he pro- 
duces "Meditation." This, as we have all seen, before, must needs be a solitary female, with head on hand, looking steadily through the opposite window at that eternal vine trellis, upon the outside, while the identical old Grecian Urn, that we have known so long and so well, sets off the window, from within! Foiled in this, no less than before, he now mistrusts he may have mistaken, either the promptings of his own genius, or the public taste; and so a third effort is expended upon what he deems a landscape. Not one of Nature's scenes, with its Maker's glory fresh upon it, no: this is too rude, with its dead branches of trees; and tangled undergrowth, and wants refining! Beside, it is too coarse and laborious an undertaking, and too replete with hardship, to go out and learn of that Nature which he is trying to place upon canvass, and which he does not despair of improving! a cluster of oleanders and geraniums, therefore, in pots, supply the originals of his trees; and these are all imagined into forest giants, and so painted; but all without a curve of trunk, or natural sweep of limb, and as straight, methodical and trim as a drill sergeant upon a dress parade. For a study of the rocks, with their mosses, that are to be introduced, an hour's lounge at the $\mathrm{Mu}$ seum suffices; and that the piece may not be wholly a country inception, and so partake of the vulgar, with.a total absence of all town "refinement," clothes are borrowed from a sportman's furnishing shop, to assist in introducing into the foreground a chap in wading boots and bobskirted fustian coat, with gun and dogs, in eager expectancy of flushing a snipe! Now, to the man with 
but a single spark of artistic genius, how truly contemptible are the complaints we hear that a love of ART is wanting among us, because such morbid abortions as these are not admired! If the authors of such productions as we have here described, and which are but samples taken at random, from our exhibition galleries, would learn the cause of their failure and neglect, let them come to the knowledge that every successful artist who ever secured true renown, in his pursuit, did so through productions which he conceived, began, and finished, in pursuance of a definite plan, for some specific and exalted purpose. Less than this has never brought just renown to any pencil, and most certainly never can.

Such, then, is the general result, thus far, of all we have believed of the old masters, and all that we have developed, through the agencies of ART organization, and otherwise, under that belief. And is there not enough of this evidence, on every hand, to convince us of the existence of some radical error in our system of approaching this subject? Yet, with all this constantly before us, and without the least attempt to develop even the elemental spirit, or conception, of what ART absolutely is, we still suppose all is attained by sending students to Europe, before they have yet learned either to think or observe, there to study the false guides they have been so constantly taught to adore. We have already said that the social position of the old masters, and the circumstances under which they pursued their labors, would, of necessity, sink AnT, as a whole, while it would minutely develop it, in some particulars. It remains, then, for us to define, more 
fully, these distinctions-not for any purpose of argument, or word victory, which would be so wholly unworthy of our subject-but to enable us to avoid, alike, the two errors of either adopting, or rejecting, these masters, as a whote. With them, then, we have by no means done; for what we have to condemn in them, is, in no sense, a condemnation, as a whole, while on the other hand, to adopt them, entire, as models, must perpetually inflict upon ART the great and essential faults which lie at the very basis of their system. To come, at once, to particulars, then, their radical defects lie in the INCEPTION of the scenes to be exhibited, and in want of Keeping, in their execution. These two radical elements of a picture, namely, InçPtion and KeEPING, involve the chief greatness in its production. We say chief greatness, because there is a certain seeming greatness belonging to each, and to all, of the subordinate and mechanical details; but all this is only seeming, or subordinate greatness, or greatness in some one direction, only; as it may be in color, in form, in size \&c. Now, to these particulars and parts, the sublime inceptions which constitute true greatness are not applicable, and do not, therefore, descend. In so far, then, as the old masters failed, in these two particulars, greatness, in its highest, or poetic-and therefore in its only just artistic-sense, was wholly wanting, in their labors; and of necessity this must be equally true of the works of all who, coming after them, shall adopt the received notions of their excellence, and treat them as models of highly perfected ART. We shall have occation, farther on, to speak more in detail upon both Inception and 
Keeping, and the particulars we shall then designate will more fully illustrate the neglected importance of these, by which Arт so suffered, in the hands of the masters. But it was upon the subordinate and mechanical details of execution that these masters spent all their strength; and there they have left us much that is worthy of the highest consideration. Of course no one excelled in all these; but taking all their labors, collectively, and we may cull from them all the perfections of which ART is capable, in these subordinates. We shall endeavor to show, in our subsequent pages, that before the artist can, with the least safety to himself or his hopes, encounter the old masters, he must have learned truth, and how to distinguish this from falsehood, by a devout and zealous study of God, in his works, where perfection is all that can ever be found, and where neither the mannerisms of any age, nor any other of the imperfections of mortals can, by possibility, have a place. When, from this unerring source, just conceptions of what ART truly is, have been derived, and fixedly secured, then these old masters, as we shall see, can be studied with profit, because with discrimi. nation.

In nothing does man more honor his Maker, or exalt himself, than through an honest and zealous investigation, and exhibition of those laws by which the Deity has established and ever controls the Universe. In these investigations he is in direct communion with the Most High, and ever imbibing both wisdom and truth from that only source of perfection: and his gra- 
titnde for this can, in no way, be more devoutly manifested than in expositions, to his fellow men, of all that has been thus revealed to him. In one branch-and in one, only, namely, mathematical astronomy-of these researches, does man, although there an humble inquirer, rise, in some sort, to the true character of a creator. There, by his soarings, in that awful sublimity, by which he penetrates space, in search of the mechanism of the Universe, no fore-shadowed law of his Maker guides him: the truths he discovers ar'e, indeed, those of the great Author of his being, but his processes, by means of which he has found out and seized upon these truths, are all purely his own-and they mark, perhaps, more pointedly than all else, the extent to which human intelligence is capable of fathoming the secrets and the resources of Nature. Now, there are points, upon the earth, where the investigators, not only of these aibstruse, but also of the more familiar features, of $\mathrm{Na}$ ture, are so numerous and concentrated as not only to constitute society among themselves, but also to exercise a marked and valuable influence upon those in whose midst they move; while it is readily seen that intercourse with these is, of necessity, a constant source of pure intelligence. But, in our new country, such men are yet too few, and too little concentrated, to produce these results. Here, therefore, the devotee struggles on alone, making but a slow and painful progress; while, as few around him either understand or appreciate his labors, the very efforts he makes only tend to isolate him, more and more, from that society of which he would, if permitted, be the mental orna- 
ment; and to which his intercourse rould be of the highest utility, were he not forbiden, by illiterate fashion, to even hint, there, at the subjects, the investigation of which constitutes alike the labor and the pleasure of his life. But, happily, these evils, which so obstruct and diminish the usefulness of men in the walks refered to, are scarcely known to the pencil artist. His, then, is far the more felicitous present; for he is everywhere welcomed, in society, for his AnT's sake; and, with the Poet's licence-for he is, if great, in ART, a true Poet-may discourse, at pleasure, of his dreams and his canvass, with no fear of offence, and no dread of indifference. He has a mission, then, confided to him, and let him look well that it be not either mistaken, neglected or disgraced. Nay, more : let him know, and feel that, in his hands, it is to be both exalted and glorified; and that the unfaithful servant, who buried his charge in the earth, and so waited his lord's coming, mistook a duty which the artist may not.

"Brutes graze the mountain top, with faces prone,

And eyes intent upon the scanty herb

It yields them; or recumbent on its brow,

Ruminate, heedless of the scene outspread

Beneath, beyond, and stretching far away

From inland regions to the distant main."

And shall man do no more than this, and still claim to be man, in the image of his Maker? While beauty, and strength, and truth, and glory, are on every side of him, shall he walk unheedingly in their midst, giving no sign that his soul feels gladness in their presence, or gratitude to their Author for their bestownent? No: man cannot do this ; and least of all can artist marı thus sink his very soul to a level with the brutes that 
perish. On the contrary, to such an one, and to all such, the ardent longing of the immortal, that is within, will constantly be present, to lift up the soul in ear. nestness and in devotion, above all that is unworthy or indifferent: and devoutly cheerful he certainly must be, since all the objects of his admiration, the works of God, constantly rejoicing around him, are a living example for his observance; yet earnest, and zealous, and faithful he must no less be, and fixed in his purpose of worthily exalting the emotions of his fellow men, in their contemplations of the parts and the purposes of creation. Such must the true artist, of necessity, be; and his aspirations must therefore constantly tend to some exalted and worthy aim, as illustrative of history, morals, or some perception of the sublime, the beautiful and the truthful, in Nature, that may excite a love and a reverence for these, and through them, for their pure and perfect source. Such, in some sort, is the true man, as he comes from the hands of his Maker. Yet, in the economy of Nature, this is not all; or, rather, it is but the supplied foundation, upon which the creature is left to rear his own superstructure, and through that to found his claims to usefulness and worth. Artists, then, no less than other men, have something to do-a work to perform-and it cannot be too deeply impressed, upon all minds, that no man ever rose to eminence through intuition. Yet it is the common fault of youth, and more especially of youthful genius, to assume this, and to act upon it; supposing that industry and application pertain only to the mentally vulgar and grovelling. It is not to be dis- 
guised, and it should never be lost sight of, that this error, wherever it exists, must be forever fatal to progress. On the contrary, let no one presume so far as to hope for greatness, whatever his capacity, except through constant and earnest application at the multitudinous sources of knowledge. The intellectual, no less than the physical, must diligently toil for results; and no one ever did, or ever will, drink deeply of inspiration, at the fountain of Nature, who has been effeminately occupied with the difficulties which beset the path of all who journey thither. The mentally frivolous may waste their time, and the world lose nothing; but genius must be ever diligent, and earnestly intelligent, if it would leave its impress upon the world, for the benefit of either the present, or the future. Man sees only what he brings the capacity for seeing, says the German proverb, and that capacity we can only enlarge, in ourselves, by enlarging the sphere of our knowledge. For instance, we all witness the effects of the power of steam, as manifested in the action of the steam engine; but witnessing this does not furnish the same suggestions to all minds. The traveller, the forwarding merchant, the rail-road, and the steamboat owner all see in this wonderful agent only a means of transporting persons and property from point to point, upon land and sea: the manufacturer contemplates it in its capacity to turn spindles and rolling mills; while the Political Economist, embracing all these views, and stopping short, there, without ever looking farther, discourses and computes upon the profits of its labors, and their results to capital, and upon 
national supremacy. Now, the investigator of Nature sees all this, no less than others; but he also sees much more. While viewing and admiring the action of the steam-engine-that child of all work-his mind naturally goes back behind all this-behind, aye, far behind, the day of its construction, or even its first inception-and there contemplates this same motive agent, steam, in its far more mightly work of aiding in the elevation of continents from deep ocean beds, and of lifting on high those giant mountain ranges which everywhere traverse and diversify the face of the earth. To the artist whose study, beside events, is Nature, both animate and inanimate, all that Nature's secrets, which are fathomable, should be present and familiar; for not one of these but will, at short intervals, demand a recognition and a place, in his works-and his highest efforts, if these have not their fitting place therein, can never rise to ART. Effeminacy, then, and indolence, in all their forms, and all the enervating influences of fashion, must the artist put far from him, if he would run his career with success; and certainly none who are in contact with these debasing elements of society, can more readily detect this necessity, through observation, than artists, themselves. Young as our nation is, we have already made such high advances in the desolating prostration of both physical and mental powers, that our oldest cities, where these evils are paramount, can seldom boast the production of a son, from city parents, whose native ability is found to bear him upward, among, his fellow men. Of refinement, in its popular sense, these cities have, indeed, a surfeit; but 
unon such conditions as leave them, strictly speaking, little to refine. The causes of this are not numerous, and are clear enough to be seen and understood. City habits, and city etiquette, demand the daily, and almost constant, violation of those natural laws through the strict observance of which the most perfect development of both body and mind, and consequently of the most perfect manifestation of these, are secured. Parents, through successive generations, sacrifice the observance of these laws; and their degenerate offspring, with a constitution undermined by the joint sins of its ancestors and its own, totters feebly along that life-wasting path in which, perchance, the father moved with somewhat more of manhood's stride. There are appliances, too, that directly withhold the mind from putting forth those powers which are actually possessed, and which thus enervate, and finally destroy these, through neglect of their use. How much of this is already verified, let the effeminate manners, body, and above all, mind, of "Young America," in our cities, answer. In these youths, all the manly efficiencies of our nature are first subdued, and finally utterly extinguished, by the deleterious toyings of miscalled refinement; and the fondness of parents, and the partiality of friends, look in vain to such victims for lofty intellectual conceptions, on the one hand, or ready and vigorous execution upon the other. These results, so indispensable to success, in whatever is undertaken, are only attainable throug the most careful observance of those laws upon which they depend; and this conformity is only to be sought in the more retired 
portions of our Republic. While, therefore, the offspring of the older city families, which sin, in these particulars, pass prematurely to the grave, leaving no mental memorial behind them, it is from the hill top and the mountain side that this nation's intellectual and physical supplies are drawn, as certainly, and as constantly, as are the running waters upon whose agency the fertility of our plains so much depend. Nor is this field of supply a stinted one: broad, indeed, are its borders; and long, we may hope, it will meet the utmost demands upon it, for all that can ennoble individual man, or exalt the race to which he belongs.

We have seen that artists require, as a means of success, an enlarged and comprehensive knowledge both of Nature and events-a knowledge that implies the necessity of diligent application, on their part, in other directions than the mere use of the pencil. The acquisition of extensive and varied knowledge, it is not to be denied, demands both great labor and great accuracy; but still, very much, also, of success, or of want of it, depends upon the manner of applying and expending this labor. One class of men investigate the principles which control details; while another class spend alt their toil upon the details, themselves, irrespective of the laws that govern them. A common example will illustrate this. In every community there are numerous persons who believe that, after floating all winter, the ice in our lakes and rivers, sinks, in the spring. Now, two individuals, each for himself, resolve to know whether it be true that ice sinks. One, on investigating the principles upon which ice is pro- 
duced, finds that water, upon freezing, expands in bulk, and that, therefore, a cubic foot of water, when converted into ice, will measure more than a cubic foot. As the weight remains the same, this fact of increase of size is at once conclusive evidence that ice must, of necessity, always float, under whatever circumstances, while not forced downward by extraneous agency. This isvestigation, which, at most, can have cost but a few hours of time, is final and conclusive ; and thronghout the remainder of his life this man never again pays the least regard to what he may either hear or read, in favor of the supposed sinking of ice-a thing he now knows to be impossible. The other investigator, who looks for no principle, and thinks of none, spends all his efforts and his time, in learning what has been said or written, by theorists and unscientific authors, upon the subject. This plan he pursues for years, or perhaps for life, all the while carefully gathering up, from newspapers, almanacs, and sometimes from works of higher pretentions, the statements and the details of those who have supposed they had known ice to sink. Now, this last person's labor has evidently been vastly greater than that of the other, and which procured him certainty, in the matter, and yet this one has literally finished life, and gone to his grave, after all this effort, without ever absolutely knowing anything of that which he sought.

The great and leading laws of Nature are comparatively few, and simple, while they are absolutely constant, and never betray us. The law which is employed by the grain merchant, in weighing his wheat, and 
by the miser in determining the value of his bullion, is identically the same as that by which Laplace balanced the distant globes of our solar system, and which has since enabled Le Verrier to direct, with unerring certainty, the telescope to that unknown planet, the certain existence of which his mathematical calculations had first established, but which had hitherto been seen by no mortal eye, nor been known to exist, by any inhabitant of our earth. Equally certain is Nature everywhere. Cuvier so interrogated her that, if possessed of any single bone of an animal he could reconstruct, from that, alone, the entire skeleton, and so determine the class and character of the individual to which it had pertained. Professor Agassiz has found the some unerring data, in his investigations of fossil, extinct fishes; beings which, of course, he could only possess in the form of rock; and yet this rock, no less than all else around us, bears witness, to the man who has eyes to see it, that organic life, and the fixed law of that life, both had being before the rock itself. Adolphe Brongniart, the father of Fossil Botany, so fathomed the laws of vegetable construction that from the trunk and limbs of one of the coal plants, which now nowhere grow upon the earth, and which he could only examine in a state of either coal or stone, determined the leaf it had borne, and the impression of which he had failed to find in Europe, with so much confidence that he gave to the world a drawing of it, for future verification. The impression of the actual leaf of that plant has since been found, in the coal mines of Ohio, and it accurately corresponds with the 
imaginary leaf, as drawn by Brongniart. Of Geology, at large, we may say, in a word, that its laws not only determine the topography of a country, and so, to a wide extent, its climate, but they also fix all the capabitities of that country, for both the purposes of peace and of war-of habitableness, and of human pursuit, therein.

So, again, of events, or history, which is a wide and fruitful field, for pencil art-the more so from the false and imperfect manner in which the historians have acquitted themselves, in their vocation. It is the work of a life, almost, to wade attentively through the ponderous works we have, of history, so called; and yet, with all this labor, very little of available truth is elicited, at last. We have almost endless narratives of rule - of domination, but not of the ruled - the dominated. Now all these may be deemed, in some sort, histories of individuals, but they cannot be so of a people. For examble, we turn to the history of France, and there read that the Franks, already masters of Tournay, and the banks of the Escaut, had carried their arms as far as, \&c., without the least intimation why they had carried arms at all. Again: Clovis, son of king Childeric, assended the throne 481 , and by his victories, strengthened the foundations of the French monarchy. Now, in all this, where are the people, whose history we are seeking? They are nowhere allowed to appear, in these formal and plethoric narratives. But leaving these policy digested fables, we can find that people, still, in the Old Chronicles. Look but at Chateaubriand's rranks, clothed in the skins of bear's, seals, and 
wild boars; and at their camp, guarded by leather'n boats, and huge carts, drawn by oxen; and finally, at their army, formed in a triangle, exhibiting to sight only a forest of spear's, wild beasts' skins, and half naked bodies: and this done, listen to the song of victory, as it rises from this living triangle, and is wafted, by the winds, across the plain:

"Pharamond! Pharamond! We have fought with the sword: we have hurled the battle axe, with two edges: sweat ran from the brows of the warriors, and trickled down their arms. The eagles - the birds with yellow feet-uttered screams of joy; the crows swam in the blood of the dead; all ocean was but one wound: the virgins have long wept!"

Substituting defeat for victory, and the breeze came burdened with lamentations:

"Pharamond! Pharamond! We have fought with the sword: our Fathers fell in battle, and all the vultures moaned at it, for our Fathers satiated them with carnage. Let us choose wives whose milk shall be blood, and shall fill with valor the hearts of our sons. Pharamond! the song of the Bard is ended-the hours of life are passing away: we will smile when we must die."

Thus sang forty thousand barbarians. The riders all raised and lowered their white shields, in cadance; and at each burden they struck their iron clad chests, with the steel of their javelins.*

There is history-a picture, complete: and history which genius may paint, too, with no fear of misconcep-

* Les Martyrs. 
tion, but with all certainty that his work, if faithfully executed, will, through all time, vividly impress the studious beholder with a living realization of what manner of being this Frank was, whose very lineaments, costume arid character we have here before our eyes. The seeker of truth-of vivid and living reality-will generally fare no better in the whole range of accredited histories, either of France or of any other countries, than in our examples of illustration. There are large portions also, of these cumbersome fictions, which fall under the common and popular appellation, entertaining. These are more or less extended efforts at mere fine writing, and often contain no history, whatever, or next to none.* A chapter in Macaulay's late history of England, which has been quoted, perhaps, more than any of his others, is a good illustration of this. It is that in which the author contrasts the condition of England, in the days of James the 2d. with the present, to show progress. Now, that progress--which, during the specified time, has been conmon to all the nations pretending to civilization, and which has been, in some nations greater, and in others less, than in England - is fully known to every one, and is a FACT, merely, but not history. But the history of this factthis progress-is what we here want. Whence came it? What were the agencies that produced it? What

*Upon the nothingness of such books as these Goetre, in his Essays upon Art, has the following:

"All Dilettants are Plagiarists. They enervate and pull to pieces all that is original in manner or matter, and at the same time, irnitate, copy and piece out their own ernptiness with it. Thus tho language gets filled with phrases and formulas stolen from all sides, and which lave no longer any meaning; and you . may read whole boolss through, written in a fine style, and containing nothing." 
the impelling forces? And what agent, motive, casual contingent, or preconceived intention put these in motion, and sustained them? If, in the midst of early despotism, a good came to the people, by legislation, or otherwise, with whom did this originate? Did either king or nobles first conceive a voluntary lessening of their own powers, for the good of the people? Or did that people, who, alone, were to profit by such lessening of power, first conceive its consummation, and then force, through circumstances, their rulers to submit to it? Again: did king and nobles quarrel about the divission of power, between them, and each party, in turn, and at various periods, appeal to the people for aid against the opposing party? And if so, were con. cessions made, on these occasions, to the people, as inducements to them to give the aid required? and did concessions thus made become henceforth vested rights -though not so intended - that could not be recalled? Full answers on these and collateral points would constitute the history of the fact in question.

We see then, from these examples, that true knowl. edge, whether of nature or events, and without which nothing can rise to the dignity of $A_{R T}$, is only to be reliably acquired by appeling to first authorities; and it is equally evident that when we have once allowed ourselves to lose sight of the true object of our research, and have become enamoured of an author's style, to the exclusion of the knowledge we sought, we may easily wear away the remainder of life in gazing at the rainbow hues upon the bubbles thus blown to amutse us, and so accomplish nothing that can endure. 
To these first authorities, then, must artists constantly and deroutly apply; and they must toil there, with ardor and with earnestness, in collecting those data by which, alone, their artistic conceptions can be guided and perfected. Genius, then, with the indicated contingents, has secured some, or rather most of the elements of success; but still, one thing more is indispensable, and that is, Moral Courage. By this we mean that courage which hesitates not, under any and all circumstances, to say or to do whatever the soul realizes as truthful duty, and which is more rare in the world, than even moral honesty: and yet, he that hesitates, either in word, or in deed, upon any subject that his position in society fairly calls upon him to investigate, and to take part in, is no man, but only an inert recepticle of emasculated truth-a species of moral eunuch. The artist, then, to rise to the point assigned by his nature, must have courage to withstand enervating examples, on every hand; to disregard the influence of place and position, as such; and to spurn all false taste, which, though it may spring from wealth or power, still, under the guise of refinement, invites puerility, discourages genius, in its healthful efforts, and deadens all true perceptions of vigorous truth: he must have courage to rise wholly above, and constantly to look steadfastly beyond, all the allurements and the mandates of fashion -in short, in the full majesty of his nature, he must be ever ready and ever able, calmly to dare and to DEFY, in his onward course, all else save only the Almighty Author of his being, and sacred Truth, which is part of that Author's nature. All this, 
thou aspirant to true greatness, must thou meet, and look steadily in the face,

"And if despondency weigh down

Thy spirit's fluttering pinions then,

Despair-thy name is written on

The roll of common men."

We have seen that the old masters had most of their subjects dictated by the Papal power; and the manner of the execution of these, no less than the subjects, themselves, was made an object of especial prelation. This circumstance necessarily, and to a very wide extent, controlled the INCEPTION of artists-of which we are now to speak. This, as we have before suggested, is one of the elements of all true greatness, in pencil art; and we feel the more earnestness, upon this head, from the fact that so little importance is generally attached to it. If we have justly conceived this subject, the pencil is worthless, unless it teach something; and something, too, that is worthy of being known and remembered. Now, although pencil art has never reached its true place in the world, and although artists, in common with others, have constantly wondered if it had, in truth, a something beyond--a mission still unfulfilled, and if so, what that mission could be-still there has abidingly prevailed, all over the intellectual world, a deep-seated, reverential passion for AnT; and a passion, too, beyond that of mere fashion, or caprice. This certainly cannot be an earnest of what is to come-or, rather, what might come-derived from what has yet been accomplished; for that is all quite too insignificant to either excite or sustain such a feeling. Whence, then, and what, is this hankering after 
something unknown, and undefined, in ArT--this something which is not even so foreshadowed, in the minds of either artists or others as to constitute it an end to be aimed at, hut still, a no less vividly existing expectancy, to which high importance is attached? yes, what, indeed, is it, or can it be, but a vague and shadowy longing after some more exalted end-some higher result-in Arr, than has yet been realized, analogous to the untutored hankerings after immortality, in the far off and unknown, of that soul to which the inspiring joys of revelation have never come : and whence comes it, or could it come, save from that only source whence all true and holy promptings ever emanated? Now, the poetic inception of true genius is excited to its most sublime action, under this very principle of our nature; and, if undisturbed, it would, through that very influence, determine the employment of its pencil upon only the most exalted and worthy objects. Whether any of the old masters, whose pictures we possess, were really great, in the broadest sense of that term, their works leave us sufficient room to doubt; but surrounded and influenced as they were, it will, perhaps, be forever impossible to determine how far these contingents are answerable for the results we have seen. With the church, of course, ART was not the object. By what she did, in this, as in all else, self-aggrandisement, and augmented secular power, however concealed, were never lost sight of; and it may well surprise the Protestant sentiment of the world, on looking abroad, to find it has never had a place in pencil art. While Europe is filled with saints, 
martyr's and miracles, upon canvass, as illustrative of Catholicism, we nowhere meet with galleries in which Protestant Christianity holds prominence, as a truth. And why is this? Is it because Protestantism has furnished no materials? certainly not, for it has been fruitful, in these, almost beyond example. Not only in the lives of individual reformers do these materials abound, but no less so in the current history of those periods when the chief enactments of man were but features of the great protestant movement. Of the former, passing over Wickliff, Knox, and a host of others, look but for a moment at Huss, and the treacherous summons of the council of Constance, which, promising him protection, and requiring him to come and defend his opinions, thus gained possession of his person, and then burned hin alive! Again, take Zwingli, the Swiss reformer, who, after carrying the great body of the Swiss with him, in opinion, and after two victorious public disputations, with papal authorities, in the presence of assembled multitudes, finally fell, upon the battle field of liberty, while bearing the banner of the canton of Zurich, against the armed assault of Catholicism upon the Reformation. Still more imposing are some of the events in the life of Luther. When all secular power was papal power, around him, this solitary monk abjured, and defied it all; and when excommunicated, he, in the midst of assembled thousands, formally burned the Pope's bull of excommunication, together with the volumes of the canon law; and all this he subsequent sustained by the moral force of his great and crowning act of appearance and defence, 
at the diet of Worms. With the exception of some of the individual teachings of Christ, this act of ,Luther was, perhaps, the highest moral lesson ever conveyed to man, by the act of his fellow. Luther was urged, by his friends, not to brave the Roman hierarchy, but be refused-urged on by a spirit within which he would not resist. See him, then, regardless of consequences, in the confidence of his strength-his single strengthand armed solely with the truth, and his reliance upon the great Author of that truth, presenting himself at the diet of Worms, accompanied by a few friends, and the Imperial herald, who had summoned him thither. Here, then, stood this lone monk, before the Emperor, the archduke Ferdinand, six electors, twenty-four dukes, seven margraves, thirty bishops and prelates, with numerous princes, counts, lords, and embassadors. Before this imposing assemblage of earthly powersand one to realize it, must go back to the existing circumstances of the time - and all eager to win the favor of the Pope, who was already incensed, in the highest degree, towards Luther, stood this prejudged culprit, and camly avowed the authorship of all his works. On the following day he entered upon his defence, and at the end of two hours speaking, crowned the imposing scene with the following remarkable language:

"Let me, then, be refuted and convinced, by the testimony of the Scriptures, or by the clearest arguments; otherwise I cannot and will not, recant; for it is neither safe nor expedient to act against conscience. Here I take my stand; I can do no otherwise, so help me God! Amen." 
Where, since the speech of Paul, before Agrippa, has the moral grandeur and sublimity of this scene been excelled?

Such are a few of the scenes in the individual lives of the early protestants; while those of a more general character-the distractions in Germany, the fearful and bloody massacres of St. Bartholomew's day, of Cabries, and Merindol; the persecutions, the battles, the treaties and the frauds that distinguished the Protestant movement, and its opposition, upon the continent, and in the British Islands, and which so long gave constant, daily rise to the most lively hopes and fears, through. out Europe-all these have filled a large space of actual history with the most exalted subjects for pencil art, while they still lack a competant protestant painter to inscribe them upon canvass.

We have seen that art inceptions, as executed by the old masters, whether dictated by ecclesiastical au. thority or originated by the artist, himself, in view of gratifying that chief power to which, alone, he could look, for support, were mostly of a theological character; and although often drawn from the scriptures, yet the details seldom omitted to inculcate the peculiar interpretations of the church. It followed, almost of course, that Anт thus cultivated, not for itself, but only as an aid to other and widely different purposes, would often be called upon to exhibit both scenes, and sentiments widely at variance with its legitimate functions. A few examples, from the multitude of these, will serve to illustrate our position. Take, for one, a painting of the conception of the Virgin. In this an 
old man is represented seated upon a cloud, from whom a beam of light issuing, penetrates a dove, that flutters in mid air. At the end of the beam appears a large transparent egg, in which a boy, tied up in swadling clothes, with a gold fringe of glory around his head, is seen lying. Below is the Virgin, in an arm chair, with her mouth open, ready to swallow the egg! Another, a picture of 1416 , represents the Virgin in a majestic seat, with the divine infant, who is seen very graciously receiving an apple, from St. Anne, who is seated upon a couch of straw. Seven years later an artist painted the Savior crossing a river, upon the shoulders of a saint, while a hermit lights the way, with a lantern. Long subsequently to this, Raphael in a piece, and amid holy personages, must needs have a figure of a satan; but believing to improve upon what his predecessors had done, in the way of this figure, he was at the pains to give it the genuine features of the Negro! The sentiment, emanate whence it might, that could dictate such inceptions as these, must, upon occassion, call for the most rigid perversion, in details; and such is everywhere so prominent a feature, in the pencilings of the past, that even our Savior, in numerous pictures where he is attempted to be represented, has far more of the studied, dissembling meekness of the Jesuit, in his expression, than of the just and true character which belongs to the author of that Christian salvation which he came to bestow upon the world. While the church, therefore, in the plenitude of its power, guided the pencils of its artists, in all cases where its interest, or its pride, was directly 
involved, the little that was attempted beside is inevitably tinctured, and very strongly, too, with this ruling bias. The Roman element, which gave not only its character, but also its name, to the church, is an element that everywhere mistakes the means for the end, and overrides the principle with the form. That element, while imbued with the spirit of extreme selfishness, constantly deifies relics, in its solitary gloominess, and is ever buisy in founding new superstitions upon these. To its perception even living truth has no life, but is inert, motionless, without progress, and fixed and frozen, by the rigor of its eternal mental winter; and it seeks to win our admiration by the display of sensuous beauties, while it promtly rejects even truth, itself, to adopt some empty symbol in its stead. Roman literature everywhere bears evidence of these truths; and art inception, cotempory with it, has been in nowise more fortunate. Just inception, then, which is forever inseparable from all true ART, because one of its indispensable and chief ingredients, was, in no degree, an element of greatness, with the old masters, who never so far comprehended their mission as even to discover the necessity of its employment.*

\footnotetext{
*Notwithstanding the multitude of scripture pencillings that have been produced, in Europe, many of them equally trivial or revolting as those wo have cited, it seems to have been reserved for the new world to exhibit, upon canvass, in its majesty and strength, that highest of all the practical moral lessons tanght by our Savior, in which he seconded his precepts by personal application of physical force, in ejecting iniquity from the house of God. When hypocrisy and mammon had jointly tbrust themselves into the very temple of Jehovah, as if to demonstrate that no place, upon the wide earth, was too sacred for their iniquitous presence, or secure from their unhallowed intrusion, then it was that Christ, while overturning, with his own hands, the tables of the money changers, and the seats of those that sold doves, denounced to them the depravity of their charactcr and calling, in that sacred but terrible rebuke, "It is written, My house shall be called the house of prayer, but ye have made it a den of thieves."

The painting of this scene which shall-as it mnst, to be tolerated-clearly retain, and justly exhibit both the oral and the physical teachings which are the oc-
} 
But if Inception is an important element in the true greatness of pencil art, as we have seen it is, we shall soon learn that Keeping is, at least, equally so; and that while the former presides only over the determination of the nature of the subject to be represented, Keeping demands a voice in every individual step of grouping, and of all else that collectively goes to make out the piece. As true keeping consists, preeminently, in maintaining the just, natural and proper relations of objects to each other, and thus controlling and directing all appearances in conformity with Nature ; and in the same manner, and to the same degree, guiding in their proper and natural direction all mental suggestions, whatever, that may arise from each presentation of objects, to the eye, it determinately involves, on the part of the artist, as before shown, the necessity of a most thorough study, and minute knowledge of Nature, in her variety, and of the fitness of all things, as judged by her standard-our only guide, in this whole matter. If we were to see painted a full grown and gigantic forest tree, in a flower-pot; or a splendidly furnished parlor, with a cook preparing a meal therein; or a fire upon the naked floor of an apartment, with the members of a family sitting socially around it: each and every of these would, by every person, be instantly condemned-they would be out of keeping.

casion of it, will secure, to the latest posterity, just renown to that artist who shall thus have well and truthfully transferred it to canvass. The name of his pieco allow us to contribute:

"Physical Suaston, ry Christ, in the Temple."

There it is: and who so shall attempt the piece, itself, let him look well to it that he bring to the task such talent, and energy, and just conception, as shall equal the exalted demands of the occasion. 
Now these are all just such violations of keeping as no artist could be found to commit; and for the very reason that all persons, including artists of every grade, are well versed in all those laws and requirements of Nature which, in these instances, would be severally violated. It follows, then, that all violations of keeping arise either through want of a knowledge of $\mathrm{Na}$ ture, and her required proprieties, or a neglect of such knowledge, when possessed. But, the mere presence or absence of objects, relatively to each other, though a controlling element, in keeping, by no means constitutes the whole of this branch of ART. If it be found admissible that given objects be presented together, to the eye, the question next arises what shall be their relative office, in the piece, and to what suggestions shall they minister? A person supplicating a favor would not be so understood, if wearing a haughty and commanding air'; as one with a look and gesture of defiance would never be mistaken for a suppliant--while an exhibition of reciprocal and gentlemanly manliness would needs differ very widely from each of these. Again : inanimate objects, if present at all, must be so because they have a part to accomplish-a suggestive duty to fulfil. This may be prominent, or otherwise; and the position, attitude--everything, in short, pertaining to each of them, must be chosen and determined accordingly. If this be not done, then, not only the intended suggestion and effect are lost, but others, and pernicious ones, are substituted. Color, toning, the management of light and shade, and even handling, it will readily be seen, not only belong to, but ne- 
cessarily enter very largely into keeping, as they all must needs go to make up the collective result which the artist, whether intentionally or not, produces by his piece. Now, in all that pertains to just keeping, except, only, in the latter cited elements of it, the old masters were so deficient that they may be said often to have wholly excluded it from their consideration. As we have not access to the works of those masters, for illustration, here, we cannot bring examples of the faults they contain within the observation of the reader. They come to us, mostly, through descriptions, which will be found, by all who are curious upon the subject, without difficulty, and in sufficient profusion, in the pages of various authors who, though they have not, for the most part, in their picture descriptions, themselves discovered the faults in question, and therefore have not called attention to them, as such, yet they have unwittingly recorded the fact, for the benefit of such as look more closely than they. The "Oxford Student" is an exception to this blindness, when he dissects a landscape of Claude, and so exhibits the manifold sins of the author, in this way, as to sink his "great piece" far beneath contempt. The old masters, to a wide extent, if taken collectively, were masters of the pencil, but by no means masters of pencil art. Some of them painted-as we wish the moderns had, and as they might, if they would - distance, without surface; which is the pure, poetic conception of space: and so they called it. Their works often exhibit, though not at the hand of the same individual, the most exquisite command of form, color, size, light and shade, and 
artistic handling; but they seem never to have learned that all true greatness lies behind-far behind-all this; and that the highest powers of artistic inception are perfectly compatible with an entire absence of all these, or of any practical readiness to execute them. Their works, therefore, are everywhere full of the unnatural and the grotesque, for which no justification or defence can be found. Take, as an illustration, the representation of angels, the rarely failing adjunct of old pictures, in which they constantly appear in fully developed, and rounded human forms, often bearing material objects, as trumpets, \&c., and always with wings, by which to support themselves in the air! Otway has told us that, to represent the beauty of angels, we paint them in the resemblance of females. This would be satisfactory enough, upon that head, did we not paint the furies in precisely the same resemblance; but the fact of giving wings to the angelic host, we know not that any rational attempt has ever been made to justify. While we esteem these to be purely spiritual existences, devoid of matter, and consequently independent of the action of gravity, we might, with the same propriety, add wings to the representation of a beam of light, as to that of an angel. Yet, because fully developed form cannot be separated, in the mind, from the suggestion of weight-gravity-angels, when painted at all, should not be thus drawn, but only in a sketchy and airy way, as the spirits of dreams are sometimes done. More than this partakes, at once, of corporeal suggestion, and so spoils all just sense of keeping. In a "Feast of the Gods," which, by some mis- 
fortune, has been preserved to our times, a common house cur is seen waiting to be fed from the fragments of the meal! This is certainly an efficient type of Roman grossness which, by its unerring suggestion, so utterly carnatizes the whole piece as instantly to divest it of all claims to farther consideration. Modern artists, whose blind admiration of the old masters has alike prevented their studying Nature, or looking for themselves, and thus discovering what is so constantly and so fully displayed before them, in their admired models, have widely sinned, in this way, even to the utter ruin of many of their highest efforts. A striking example of this is found in the great picture, by David, of Napoleon crossing the Alps, engravings from which are met with in all parts of this country. In that piece the artist has placed Napoleon upon a fierce and rearing war charger, which is endeavoring to scale the mountain heights. Now, there were numerous scenes in that man's life, in the representation of which this would be strictly appropriate, while in the present one, scarcely anything could be more absurd; as it has nothing either to recommend or to defend it. The horse is often a fit and striking emblem of physical porver. $\mathrm{He}$ is a strong swimmer, and contends, successfully, with waves, or currents, where man could not prevail. His fleetness, too, giving force to his shock in battle, is often available, as an emblem of this same powermaking him a prominent object in battle scenes. But here, through the fault of the artist, we have him exhibited in an effort where neither his physical power, his fleetness, nor any other of his known qualities, fit 
him, in the least, for the task assigned him. So clearly evident is this, to every one, that the fact takes instant possession of the mind, upon looking at the piece ; and, of course, all regard for the painting, whatever may be the merits of its mechanical execution, is destroyed by this gross violation of keeping- A more recent piece, by Delaroche, and illustrative of the same event, represents Napoleon upon a mule, that is carefully picking its way along the mountain path, preceded by a guide. Now this is incomparably better-is perfect, indeed-in its keeping, while it is historically true; in both of which particulars David was wholly at fault. The mule, it is well known, is the best fitted of all our domestic beasts of service, for mountain climbing: it is for that reason that it was employed, for this, upon the Alps, by the French general; and it is for identically the same reason that any artist is inexcusable if he do not employ it in his picture, also. Another equally available instance of want of keeping, because scattered everywhere among us, in an engraving, is from the pencil of Sir Joshua Reynolds. This is his picture of Mrs. Siddons, as the "Artist's Bride." We have here, in the foreground, a female figure, with an open sketch book, in the left hand, showing figures partly drawn, while the porte-crayon occupies the right hand, and the eye regards some object that is to be drawn. Upon the right of this figure is an urn, and on the left a marble or plaster bust. The back ground is partly filled with a curtain, so drawn aside as to expose a portion of sky, and parts of some trees. Now, from all this there is not the slightest suggestion of an 
artist's bride to be gathered, either naturally, from the objects presented, or from the grouping, employment, or anything else, of any, or of all of them. You are not even led to suspect that the person before you is a bride, at all. The only / suggestion obtainable from viewing the piece is, that the figure in question is that of a female artist, or rather an amateur, perhaps, from the dress, and the gingerly manner of holding the portecrayon; and yet nothing of all this was intended, by the artist. The picture, then, by every rule of art, is a total failure, not even conveying the faintest suggestion of the artist's intent, but worse than this, exciting impressions, and fixing conclusions in the mind, directly at war with his every purpose. While such are constant failings of the "great masters," both old and new, there is no room left for surprise that there are now among us many pieces, of far more recent origin, which are actually deemed specimens of art, by persons acting both officially and individually, that only require comparing with Nature to show to all grades of capacity, one would think, the great gulf there is fixed between all such and the most distant approach to ArT. These facts, of course, leave nothing, whatever, to be said of those Nature defying monstrosities which so generally constitute the great mass of the collections we meet with in exhibition rooms, and no less frequently find suspended in the parlours of such as choose to employ this effectual method of giving publicity to their standard of art appreciation. We do not propose, here to produce a detailed critique upon the mechanical execution of these, but even nov- 
ices should hardly, in an ocean scene, for instance, be willing to receive, for the combing of a wave, a white shelf, standing rigidly out from the top of a solid, perpendicular wall of turbid green; nor, in a landscape, to believe that soiled and crumpled paper; notched upon its edges, because hung on a tree, is the fittest representative of flakes of leaves, in sleeping sunlight. And to what purpose, we may now ask, shall we longer either perpetuate or encourage this coarse and grovelling species of pencil buffoonery? It evidently can have no other effect upon Arr than to aid in its farther extinction, by either suppressing or preventing all just perceptions of it. Such a prospect is too humiliating to be contemplated; and it is time that the genius of the new world arouse itself, make manifest its supremacy, and relieve us

\section{From this toil}

Of dropping buckets into empty wells, And growing old in drawing nothing up !"

Aside from portraits, which constitute, at best, but a very subordinate feature of ART, and family groups, that occupy one grade higher, in the scale, Historical and Landscape painting are undoubtedly to give pencil art its future great and imposing developement, among us. It is in these fields, and particularly in the last mentioned of them, that so little has ever been well done, anywhere; so that, while it is the field that was always the most wide and ample, it has been the least cultivated, and is still the least known. The vicious manner, no less than the perverted objects, of cultiva. ting pencil art, both old and new, in the old world, may in some degree, account for this. But with us, as 
we have seen, Ars, like man, himself, enters upon a new career, and with entire new relations to both itself and to society. Here it must not-with impunity it cannot-offer us ideal landscapes, and ask their acceptance, as Nature. Such things, if they must needs be, must be produced, and must exist, outside, and beneath, the range of Ars; and, like depraved or trashy books, can find favor with none but congenial minds. We have seen the process by which these falsities, these ideal landscapes, are manufactured-for that is the proper term-with a total absence of every thought and conception that should enter into any pencil production. The mind that could thus employ itself could not attempt even a spur of the Hudson Highlands -which is as far from "town" as either such a vulgar mind, or its body would dare venture - without assisting Nature, by some such addition as a board and shingle toy that it would name a Grecian temple, forsooth! and placed, of course, in a position to equally defy the approach of either gods or men. For such a being to talk of either Nature, or AnT, is downright profanation. He is the just counterpart of Irving's chap, who, without ever having been beyond the London pavements, stuck a rose in his buttonhole, and strutted up and down the Regent's Park, babbling about green fields! Meet this prodigy where you will, and he prates flippantly and constantly to you of the classics; and yet, were you to present him the Nectar of the gods, in a goblet of light, his very nature would needs convert the gift to stagnant water, in a vessel of dishonor!

The landscapist, then, must commence, and pursue 
his labors of successful usefulness, by a careful and devout study of Nature; from whose works he must store his Port-folio, piecemeal. Nature's sublimities and beauties are sown, indeed, broadcast throughout every part of creation; and he that would enjoy these, or transfer them to canvas, for the enjoyment of others, must study them in their unobtrusive existences. From these retreats the enthusiast-and none but enthusiasts will ever enjoy, or even visit them, there-may bring them forth, to exalt the conceptions and promote the devotion of his fellow admirers of that great created whole, of which each of us constitutes a part. But these sublimities, and these beauties rarely occur in such groups as to be all made available, by the pencil, in the exact connection in which they are seen. Hence he who would employ them, must gather them, detachedly, for future use. Sky, in all lights, clouds of all forms and colors, sweeping curve, wavy outline, and jutting peak of distant highlands: mountain gorge, foaming stream, and trickling rivulet: trees, from single shafts, to clumps, and whole groups: faces of rock, in their endless variety of structure, form and condition: all these, and so down to the very tuft of moss, which, though surrounded by forest, stands boldly out, in relief, from impending shadows, illumined by a full, broad pencil of sunlight, that steals down through the foliage, and lights up the mimic structure with radiant glory: these and kindred sketches, and in all possible forms of multiplica tion-but not of repetition, for Nature never repeats herself-will be found perpetually accumulating in the Port-folio of every artist who seeks the scenes where 
they dwell, and has soul enough to seize upon them, for the lessons they teach, and reverence enough to wish their perpetuity, for the glory of their Maker. We know, very well, that this is not the way landscapists have worked; and we know, too, that it is precisely because they have not so worked that we have never had landscapes, except in name, from pencils either old or new. Ideal, or imaginary landscapes are certainly very "vain imaginings," to say the least, and can, by no possibility, claim affinity with pure ArT ; since any piece, to do this, must contain no semblance of any material object which has not been actually painted from such object, existing in Nature.

Such, then, are some of the indispensable preliminary requisites for producing a landscape; but still the difficulty of that production, itself, is yet all to come. We have spoken, before, of greatness; and we cannot too strongly impress it upon the reader that an artist may be highly gifted in executing the form, size, color, \&c. of objects, and still have no just claim to the term great; because each of these qualities is the result of an individual power, exerted singly, for its specific end. The landscape, entire, that is to come of these gatherings, is still to be produced. It is to be constructed out of these elements; and it is the employment, and the grouping of these that will test the diversity of talent, and the true greatness of the artist. When the keeping of the piece demands, in a given part, a certain tree, or rock, or any other specific object, then no other tree, nor rock, nor any other thing, in the wide world, can be substituted for that, with impunity. It 
is not that something else may do; for more frequently, perhaps, nothing would do just as well--in other words, would spoil the piece just as effectually, though very seldom, if ever, more so. In the employment of each individual object, then, the artist has to give it the precise relation, in all respects, which Nature would have given it, to each and every other part and portion of the piece; while no objects which Nature would not exhibit together, of course, can be allowed a place upon the same canvas. The separate drawings, then, it is readily seen, when made, are not, so far, any portion of the picture of which they may form a part; for, as yet, that picture, itself, is not conceived, and of course has not even mental existence. Some one has 'said that,

"Roots, wood, bark and leaves, singly perfect may be,

But throwu hodge-podge together they don't make a tree"-

and even so is it with our gathered materials, and the landscape to be formed from a combination of them. In short, the elements of a landscape exist separately, but the piece, itself, is created by the grouping and employment of these elements. While uncombined, such elements are as individual, in their character, as the words of our language. These last are the only elements of which we can construct sentences, and they are alike accessible to all; and yet all cannot equally well employ them, in composition, and its legitimate pur. pose, namely, the conveyance of thoughts, sentiments and emotions. Ignorance of Nature, in this process, is inevitably fatal, both to the artist's reputation, and to the character of his piece; since it is sure to produce a 
landscape monster, for which nothing can atone. To illustrate our position, suppose the artist has occasion to let down a stream, suddenly, from a higher to a lower level. This he knows is only to be done by introducing rock into the banks and across the bed of his stream. He knows, too, that he may have either a perpendicular fall, or he can employ a sloping face of rock, which will produce a rapid, only. But knowing this is not enough: he must also know what kind of rock is demanded by the contour of surface, and the character of the vegetation he has chosen, as these will determine the nature of the descent of his stream. This done, his next care will be to represent, in the banks, not merely some rock, but that identical and particular rock which has given character to every part of his piece. So, again, with hills and mountains. The forms and the vegetation of these are no less positively determined by the character of the rocks composing them. In the case of these it is farther true that great elevation is an element in controlling the character of the vegetation. Upon the Andes, Humboldt employed this law to form a species of vegetable barometer, by which he was enabled to fix, with much certainty, the heights of the various elevated regions which he traversed. But in all lower and cultivated lands the artist must know the control which rocks exercise over vegetation; and that in a picture, for instance, where granite, porphyry, trap, mica slate, sandstone, and some others, either one or more constitute the only: rocks, a growing and thrifty field of wheat would make that landscape as unnatural, and therefore 
constitute it as perfect a monster, as would be the representation of an animal having the body of an $o x$, with the feet and head of a bear.

If artists, neglecting the trifling puerilities which effeminate fashion and devouring indolence suggest, with cultivated perceptions, will but go out, in the spirit of a man, and look abroad upon the world, as they may, neither sublimity nor beauty will be found wanting. To the true man, the endless glories of the Creation are ever present-ever visible; nor can his spirit, for one moment, realize that presence without ardent aspirations to partake of these glories, by mingling with and becoming part of them. How the spirit of Byron rises from earth, as it were, to share the sublime and the beautiful, with the elements, in his stanza upon the mountain thunder-storm, at night:

"The sky is changed!- and such a change! Oh night, And storm, and darkness, ye are wondrous strong,

Yet lovely, in your strength, as is the light

Of a dark eye in woman! Far along,

From peak to peak, the rattling crags among

Leaps the live thunder! Not from one lone cloud,

But every mountain now hath found a tongue,

And Jura answers, through her misty shroud,

Back to the joyous Alps, who call to her aloud! "'

Now, had pencil genius and art perception but been present with the Bard, upon that night of elemental glory, how would its canvas, ere now, have glowed with the realities of that heaven born scene! And yet these scenes are every where, upon mountain and plain; ever teaching-ever calling upon the creature to behold and admire-and yet how few appreciate the lessons they bring! We are aware there are those 
who, unable to appreciate this extract, have charged its production to the fumes of wine; and a facsimile of the original of the stanza, found among the papers of the Bard, has been published, in some editions of Byron, to sustain the charge. The manuscript page thus adduced in evidence, is within the reach of all; and it bears upon its face undeniable marks of the very storm it describes. It was evidently penned in the open face of heaven, by the uncertain and fitful gleams of the lightning's flash, while "the big rain" fell thickly upon it, mingling with the ink, and spattering this over the rudely traced lines. Clearly it was thus that the poet painter secured a record of the impress his soul recieved from the majestic glories of the scene before him. It is difficult to conceive the grovelling carnality of that soul wich could deem inebriety an aid in the interpretation of the hand of the Almighty, as manifested in the sublimities of elemental war. In the ensuing stanza, his spirit still soaring among the manifested emblems of the Divinity, the Bard continues:

"And this is in the night:-most glorious night!

Thou wert not sent for slumber! let me be

A sharer in thy fierce and far delight,-

A portion of the tempest, and of thee!

How the lit lake shines, a phosphoric sea,

And the big rain comes dacing to the earth!

And now again 'tis black-and now the glee

Of the loud hills shakes with its mountain mirth,

As if they did rejoice o'er a young earthquake's birth."

Oh! that some pencil, guided by such a soul, would trace for us, in scenes like this, what all may look upon, but few can see, and fewer still can thus make part of themselves! 
Contrasting strongly in character with this, and no less perfect, in its way, is the following, from one of our own poets:

"How dear to this heart are the scenes of my childhood,

When fond recollection recalls them to view!

I he orchard, the meadow, the deep-tangled wildhood,

And ev'ry lov'd spot which my infancy knew;

The wide-spreading pond, and the mill which stood by it,

The bridge, and the rock where the cataract fell;

The cot of my Father, the dairy-house nigh it,

And $\theta$ 'en the rude bucket which hung in the well!

The old oaken bucket, the iron bound bucket,

The moss-covered bucket which hung in the well."

There is a minute and completely artistic landscape, in a map of childhood's home. See how all the parts harmonize, and yet so fill up the piece that nothing is wanting! We can almost hear the brawl of this mimic cataract, as it mingles its hushing note with the subdued and jaring rumble of the adjacent mill. And then that bucket! It was old, was of oak, bound with iron, and covered with moss! Now, should any pencil ever attempt the picture here so vividly drawn by the pen, we charge that no sacrilegious perversion of the apparatus of this well be made. If the artist be a son of New England, whose boyhood was spent at such a home, all will be well, upon his canvass, in this respect; but if not, then let him beware that he give to that old well no windlass, or other town devised figment, at his peril! No: the identical image which occupied the author's mind while penning this, must be preserved; the primitive well sweep-and the reader need not stop, here, to debate if this be an admitted part of speech, in his school English, or no, for, be that as it may, nothing else will do-the old 
well sweep, both in form and in use, must be there, suspended, near its middle, upon a bifurcated post, and having its outer end loaded with a log of wood, or a stone, to assist in balancing this identical old bucket, and its crystal burden!

The remark is a frequent one that no artist has ever yet really painted snow-piled mountains. For one familar with scenes of this kind, as Nature presents them, it is not difficult to realize that, to do this, successfully, something more than mere mediocrity of capacity is requisite. To represent a mountain covered with a pellicle of snow, is certainly no very difficult thing, although this has often been so done as to be in danger of being mistaken for what was not ment; but to seize upon the wreathed and fantastic forms and jutting precipices into which the deep snows of mountain winter are piled, by the fitful and raging tempest, that so often makes part of the storm, itself, and to transfer all this, with the spirit which constitutes its very soul, to canvass, will certainly be evidence of powers of a high order: and it is quite safe to predict that, with these powers, the successful artist will be one whose youthful days were spent, and earliest inspirations drawn, amid these identical and imposing scenes. Yet, if Nature has been neglected here, by the pencil, so has she elsewhere, and almost everywhere, no less. Who, for instance, has ever painted either a bank of fallen leaves, or a field of grass, and these loaded with dew, and glowing in morning sunlight? or a western rolling Prarie, with its radiant carpet of blossoms and of green? or those broken masses of 
white, fleecy clonds which are so often seen driven rapidly across a clear sky, while their buge, irregular and jagged shadows seem pursuing each other, as if in giant sport, along the profiles of adjacent mountains?-or, in a word, one in a thousand of any of those manifestations of the Almighty which constantly surround us, from whatever point of view we deign to look abroad! Again, historically, what pencil has really drawn that hallowed and sacred domestic scene, a primitive New England Thanksgiving dinner? Yet, from the pen, here it is; and the pen, too, as each and all who can feel the picture, will testify, of one whose soul, in youthful days, has been part of what he describes:

"It is matter of thanksgiving that such a national usage as thanksgiving exists. To many of us it is not alone a day of thanksgiving, but of reminiscences. It is one of those magic glasses through which we look fondly back upon our childhood, and looking, feel the young blood still in our veins, and the sparkle once more in our eyes. How well I remember the month long expectation of thanksgiving-the famous plans of all surpassing merriment that were to crown the long wished for day. We counted the weeks, we regulated the events, by their relation to this joyous era. It was a time when every man was to be glad, on principle. In New England, not to be merry, on thanksgiving day, was a sin almostas great as to be merry on Sunday. What strange inconsistences are wound up in man, and insociety! Among a people whose stern and unflinching habits had been founded under religious persecutions, nourished in exile, and confirmed by the 
most resolute enterprise, upon the most impracticable soil-whose habit was sobriety, whose abomination was frivolity, whose words were few and measured, whose thoughts were high and sincere-that, among such a people, there should have sprung up such a joyous custom as this, of redolent, laughing, romping thanksgiving, is indeed surprising. All sources of unusual mirthfulness were dedicated to this day. It was religious on thanksgiving day, to say to the whole man, 'go forth, and shine, with unrestricted glee.' At other times it was their business to labor, gravely to discourse, seriously to study wisdom. On this day their supreme business was to be happy. All people, princes, and all the judges of the earth, both young men and maidens, old mell and children, were on this day to praise the Lord. When, to our exceeding joy the proclamation was read, on the preceding sabbath, announcing that the time had come, no school was strong enough to hold us, from proclamation sunday to thanksgiving Thursday. Then dispersed relatives began to gather homeward; scattered children found the old homestead dearer than ever; the young mother came back, and wept on her mother's arms, that she brought back with her one dear child less than last year; or the young wife wished eagerly to show that marvel of the earth, her new-born, first born child! It is agreed that, never before, was such a child born. The stalwart youth recounted his plans and profits; and all vied, each with the other, in bringing out of their memories the various events of the fleeting year, and to pour out their hearts into the 
sparkling stream of family converse. This custom, contrasted with the ordinary usages of New England, had, within itself, the most amusing incongruities; it was a day both sacred and secular, religious and profane, of worship and unbounded merriment, In theory, then, there is no discrepancy between these qualities; but the process of practicale xercise, when conducted by young and old, made the most singular contrasts. The gubernatarial proclamation dehorted every pious citizen on that day to abstain from secular work and exhorted him to give to God's house his peculiar tribute. There was, therefore, a wholesome scruple, throughout the forenoon. The sound of the axe was not heard. The far off report of some vagrant's rifle brought down the execration of good people upon the profanation. Such spontaneous customs are the exponents of character, and a nation whose feelings are expressed by such annual usages - the most entire abasement and humiliation before God, and the most joyous thanksgiving-were not made of such flimsy stuff that we can afford to ridicule them."**

There it is, in one of its many phases, at least; and so is somewhat more of the day, itself; and numerous are the descendants of New England Pilgrim Fathers whom no price would restrain from possessing pictures of such a thanksgiving dinner, and various other no less impressive types of that peculiar day, and its usages, as primitively revered, were these laid upon canvas as truthfully and as feelingly as they here stand in print.

But we shall be told that if artists are to pursue

* Reporter's extract from an unpublished Thanksgiving Sermon of the Rev. Henry Ward Beecher, at Brooklyn, New York, Nov. 1848. 
the methods here indicated, a whole lifetime will be consumed in the actual production of no more than two or three finished landscapes. It is very true that, if each artist always collects his own materials, such would be the result; but then these two or three would be such pictures as the world never before saw; and they would give the first just idea of the fact that, as yet, there has been no real landscape painting: and these two or three would do more for the true fame of ART than all that had gone before them. Still, the powers of true greatness must not, and need not, be thus wasted, by those who possess them. Not that greatness may house itself, as it hitherto has done, and absolutely study only within: it must go out, and abroad, and observe and learn there, until it knows Nature; else its highest aspirations will eventuate only in disgraceful caricature. But this done-Nature once thoroughly learned, in her dwelling place-and the rest may be left to others; for there is a method, we think, by which, in this country, the scattered materials may be gathered, and placed at the diposal of genius, by other hands: by hands every way competent to that, aud yet by no means equal to the higher task of truly employing these isolations, when gathered and presented for use. The method we would suggest, and the one to which we allude, for this purpose, is the founding of

\section{G A L L E R I ES}

for the purchase and preservation of these detached materials. This may easily be effected, with the requisite funds; and these are probably much easier obtain- 
ed than may, at first, appear. Although Art fails to find, in this country, either church or nobles to support, while directing it, the very absence of these is the true element which will provide it a much more healthy, certain and vigorous growth among us, at the same time that it will thus become part of us, and of our very thrift. The absence, here, of those elements upon which ARt has relied, in the old world, is precisely the cause why our social and political condition has rendered the accumulation of property, here, more universally easy and certain than in any other country upon the earth. The inability, too, of the possessor to entail this property, under our laws, renders it impossible to retain estates in families, with any certainty, and therefore more disposes persons, while living, to bestow portions of their wealth upon objects of acknowledged public utility. The same cause operates-except in occasional instances of folly-to prevent the erection of costly and extravagant dwellings, by the citizens of our Republic. The absence of the power of entail, and the general repugnance to partial wills, renders such property unavailable to heirs, upon division of the estate, and hence usually results in excessive, and sometimes ruinous, sacrifices. Colleges, schools and libraries are, at present, common objects of encouragement, in this way. Now let pencil art but get a fuller hold of community, by deserving it, and this, too, would then be remembered by such as had learned to prize its teachings, and its power. A fund, possibly small, at first, but soon to become axaple, might be realized, out of investments perma- 
nently made, for that purpose, for the purchase of separate oil paintings, of every variety of kind and character, that could, by possibility, enter into landscape pieces. These, of course, would be gathered by those whose taste and capacity led them to that pursuit; while the ample compensation paid for all suitable pieces, would engage men in the work, as a profession. They would require to be prepared according to some general directions, and must be of sufficient merit, both in selection, and in execution, in the estimation of the appointed judges, to entitle them to a place in the collection. These would be mostly produced by persons who, for reasons already given, could do thus much well, and yet would certainly fail, as composers of the entire pieces of which their contributions were to form only parts. Still, this pursuit may well be supposed calculated to elicit talent of a higher order; and in some instances, at least, it may be presumed it would do so, and thus promote, more directly, the higher branches of ART. The pieces thus produced must be wholly detached, and independent, embracing only what was obtained in unbroken connexion, at a single view, and without the slightest attempt at grouping them into pictures-keeping in mind that the only object in possessing them is that they may form parts of future pictures, by other hands.

Such gallaries as this, the result of endowments, might be established in each of our chief cities, or other favorable points of access; and these might continue to augment, though all future time. They should embrace all objects of Nature, whatever, that could 
ever enter into, or form part of, a landscape, and these in all their varions natural conditions. The same object wet, dry, or surrounded by, or partly covered with snow, would, of course, present different appearances; and these would be suited only to different pieces. The time of the year, of the day, the state of the weather, the tone of the clouds and sky, the light or shade in which the object is painted, the distance of the point of view-all these, and whatever else may effect the object, artistically-are equally important; and all, together with the name of each object in natural history, botany, geology, \&c. with its actual locality, should be plainly written upon the back of the canvas on which it is delineated; and all these, for better security, should be copied into books kept at the gallery, for that purpose, with suitable numbering, to ensure perfect identity. In making these collections, the manner of their execution is all important, and must by no means be overlooked. The nature of their future use requires that each object be elaborated, to the point of the utmost perfection, until it become, in every particular, so far as possible, an exact representation - not imitation - of the original, in Nature. Now, we do not mean, by this, a mere carnal portrait of Nature, but an actual exhibition of that Nature, upon cavas. In the landscapes, where these are subsequently employed, the case will be widely different. There, each object must be wrought with just so much labor and detail as its place in the piece, and its relative importance to the entire effect of that piece, demand-and no more. Gathered in view of these 
facts, and with a strict observance of the objects to be attained, how eternally diversified would the contents of such a gallery become! A decaying stump, for instance, or the prostrate trunk of a tree-why one of these, alone, would almost furnish study for a month: and yet, paint as many of them as you will, in all the various seasons, and conditions you can find them, and the very next one you meet with, in the forest, will present little or nothing in common with all you have done, but will offer, instead, new and equally desirable material for your pencil. A log, quietly resting in the water, beneath an impending bank, overhung with willows, may sometimes be seen to have a frog resting upon it. The frog, in such a case, must be painted with the $\log$; because Nature must be taken, in these pieces, as the artist finds her. In the future picture, where some log is to be employed, a frog may mar the keeping; in which case it must be omitted, or some other log be employed. Again: the keeping, may reject the frog, and yet require a terapin, or a water snake, or some wading or swimming bird, or a fish hawk, or a detached and decaying tuft of grass-for each of these is sometimes found upon a log, in the supposed condition, and either of them might, therefore, be demanded, by the keeping of the piece: But, if either of these is wanted it must be found on some other canvas of the gallery, whence it will be taken, by the artist who is to employ it. Now, if the painter of these materials for future pictures once deviate, in the least, from what he sees before him, we shall then know not where he will stop, or what viola- 
tions of Nature's keeping he may present us. $\mathrm{He}$ paints us a wild stream, as he sees it; but allow him to imagine ducks upon it, where there are none, and he will be as likely, perhaps, to exhibit them swimming with the current as against it, in search of their food.

Now, to galleries thus produced, and constantly augmenting, under suitable regulations, all artists should have free and constant access, and be there "fully provided with suitable room, light, \&c., for each to pursue his calling; and this free of all charge, whatever. With such collections of such materials before him, the artist of true greatness, and competent acquirements, who should come to his work with a full realization of what he is undertaking, and a confident knowledge of what will be demanded of him, to ensure success, would produce pictures such as have been nowhere seen, and such as would, as it were, from necessity, contain and exhibit perfection and strength, sublimity and beauty, such as have hitherto been quite generally supposed wholly unattainable. The question may here arise, in the minds of some, whether, under such arrangements as those proposed, these galleries would not become the haunts of lazy and incompetent pretenders, who would expect thus cheaply to do, what they would never, themselves, think of collecting the materials for. For ourselves we confess, we see no such dangers ; for the sane use of the materials in question would involve a knowledge, aside from all greatness of power, such as lazy pretenders, or pretenders of any sort, are not found to possess. The contents of these 
galleries would only be available to such as had fully compassed all the details of knowledge which belong to the use of them; whose familiarity with the laws of Nature to which they pertain would give instruction, how, and when, to employ them, and whose enthusiastic love and study of that Nature, in connexion with all this, had imparted the capacity to employ each object only in its proper and natural relation. All, save such men, who should attempt to make use of the materials of these gallaries, would, and could, produce only monster pictures, the first exhibition of which, to skilful eyes, would fix upon them such thorough condemnation as would effectually prevent all future attempts of a like kind. Instead of finding ignorance employing these materials, we think it far more probable, especially after the public, at large, shall have had a brief time to become familiar with true pictures, that even genius, itself, will often hesitate to act alone, in applying them to canvas. Certain it is that, in historical pencil art, most frequently, and perhaps in landscape, also, the subject may very justly, and with great profit, engage the best powers of various, because variously informed, minds, upon the details of a single grand result; and quite probably each of the higher future achievements of Arr, in both those departments, will be the joint production of numerous intellects, and a single pencil.

With circumstances such as we have seen surrounding us, and with the peculiar incentives that perpetually urge us forward, if we do but approach the subject as becomes both it and us, what may we not justly 
hope of prospective art development, as an element of our future nationality? Historically, nations must first enact the ART they are to perpetuate; and to these enacted materials, competent minds, justly trained to originality and independence, will give the forms of attractive and enduring imbodiment. And ours has certainly been enacted, without stint. Nowhere in the wide world has a people, before, in the brief space of half a century, after starting forth from collonial bondage, enacted so much, and that so nobly. That continental Congress; the Declaration of Independence; the long and bloody war which followed it; the glories acquired in the scenes of triumph, of suffering, and of virtue resisting temptation; the prison ships; the frost and nakedness of Valley Forge: the waxing and waning fortunes of battle fields; the dreadful reverses upon Long Island, before Philadelphia, and elsewhere; the treason of Arnold; the triumphs at Silillwater, Trenton, the Cowpens, and kindred fields; the storming of Stony Point; the seige of Yorktown, the night attack there, and the final surrender, crowning, as it did, the bloodstained toil of years with peace, and acknowledged Independence. Next the inception of our glorious Constitution, with the minds that matured, and the virtues that vouchsafed its adoption. Then, and consequent upon all this, comes the proud career of our nation, Gothic in her origin, character and efficiences, and emulous in her giant march to greatness.* Her science applied

* Both the blood and the character of the New England Pilgrims were purely Gothic, and with no Saxon taint of degeneracy. 
to the arts; her steamboats, first traversing her own mighty rivers and lakes, and then first upon the broad oceans, under her youthful, guiding hand, but now the familiar, daily servant of civilized man, throughout the world: her canals; her railroads, and her locomotives; her electrical telegraph, by which the vast distances of her continent are annihilated; her inventions in machinery, for the thousands of results which these now daily work out upon her streams : her system of social freedom; her Free Schools, for the people, sown broadcast over the land; her temples to the living God, and the rights with which man there meets his fellow man, to worship that God, with no dictator but his conscience, and no accountability for his belief, save to the great Author of his being.

Then a word upon the theatre of all this mightythis majestic ArT enactment. Stretching as does this goodly land of ours, from ocean to ocean, across a mighty continent, from the rising to the setting sun, the features impressed upon it, by its Creator, are not less imposing than is the problem of humanity which, under that Being's auspices, His creatures have here wrought out and developed: Her mighty rivers, rolling their silent tributes thousands of miles to the ocean; her towering ranges of snow-capped "mountains; her trackless forests and her inland seas: her vast, and almost boundless prairies, stretching farther than the eye can reach, and spread with waving carpets of the most luxuriant flowers; her giant cataracts, thundering in their ceaseless majesty; her mammoth caverns, traversing mile after mile, earth's inner darkness, and un- 
folding Nature's secret, hidden workings, there, in all the diversities of hill and dale, mountain and valley, stream, cataract, lake, and outstretched plain, and all within the very bowels of the globe on which we tread; and finally, the rich and varied hues of her forest foliage, unrivalled, perhaps, for beauty, in the world. These are some of the material now ready at hand, from which to develop National Art. And was ever material more rich, varied, or abundant? Most certainly, never. Nature has been profuse to us, almost beyond comparison; and our Fathers have most nobly, and most variedly, too, enacted for us, National Arт. But, before these precious materials can be duly employed, the MINDS that are to fashion them must be produced, by proper training. All copying-all vassalage to foreign styles of thought or mental fashionmust be wholly abandoned, and broken off, and a discipline entirely consonant to that free, mental and physical condition of man, as here existing, under this new order of things, be energetically entered upon, and systematically pursued.

When this shall have been fully and efficiently done, then, indeed, we may look for philosophy, history, poetry, science, belle-lettres, \&c. alike from the pencils, the chisels and the pens of Americans. Then will our countrymen no longer look, as they now do, upon a statue of their own Washington, fashioned by a foreign hand, ANd olad in the toga and sandals of Rome! Yes, for all these we may then look, nothing doubt. ing; for, from such contingent, happen when it may, will issue a National ART-a literature, indeed, using 
the word in its broadest sense-such as the world has nowhere seen; bearing upon itself that impress which it must receive from the materials, themselves, and necessarily partaking of a character and a philosophy more elevated and more perfect than have pertained to other times. 

